\title{
Angry Preaching: A Grounded Theory Analysis from South Africa
}

\section{Casparus Johannes Wepener}

Professor and Head of the Department of Practical Theology, Faculty of Theology \& Religion, University of Pretoria, Gauteng, South Africa. cas.wepener@up.ac.za

\section{Hendrik J.C. Pieterse}

Emeritus Professor of Practical Theology, Department Philosophy, Practical and Systematic Theology, University of South Africa. pietehjc@absamail.co.za

\begin{abstract}
Expressions of anger can be observed all over South Africa and by individuals and groups from different social, economic and racial backgrounds. In this article the argument is advanced that such expressions of anger can be expressions of love and signs of hope showing that people still care. Therefore, anger should not be avoided, but instead be embraced and channelled for positive ends. This article furthermore develops an argument in favour of the celebration of angry liturgies and the preaching of angry sermons as an integral part of the ongoing road towards reconciliation and healing after apartheid in general and in particular it reflects on sermons preached in Afrikaans Reformed churches in South Africa on the theme of anger between 2010 and 2015. By means of content analysis, and specifically Grounded Theory, the collected sermons were analysed and a homiletical theory for praxis regarding angry preaching developed. In conclusion the theory for praxis is presented as homiletical route markers for angry preaching as one way of liturgically embracing and meaningfully channelling anger.
\end{abstract}

Keywords: Preaching, Homiletics, Practical Theology, Anger, South Africa, Reconciliation 


\section{Introduction}

In this article the authors reflect on the potential value of embodied and enacted expressions of anger in the current South African context in general, and more specifically, on the possible role of preaching in a context of anger. ${ }^{1}$ In the year 2018 South Africa is a very angry nation. The South African theologian Tinyiko Maluleke wrote: 'some of the angriest people on earth, at this time in history, are to be found on the Southern tip of Africa...' and, again, '... a centimetre beneath the smiles and cordialities lies a latent anger.' Regarding the Truth and Reconciliation Commission (TRC) he writes: 'If there is one area in which the TRC failed and failed spectacularly, it is the area of anger. We are an angry people. This is an angry nation.' ${ }^{2}$

This is not the first time in South Africa's recent history that public anger can be detected. In 1976 the Soweto uprising, which started as a protest against Bantu Education, led to widespread protest action after June 16 in which 176 people were killed. Ten years later, in 1986, South Africa was in a so-called state of emergency as the apartheid government tried to clamp down on the heightened unrest in the country. In 1996 the country was engaged in the already mentioned Truth and Reconciliation process, of course under a beautiful rainbow, but horrified whilst listening to the stories being told. ${ }^{3}$ In 2006 South Africa was under the leadership of President Thabo Mbeki. Although he did much that can be commended, his

\footnotetext{
${ }^{1}$ In this article anger is viewed as an emotion that is perceived through the human body and that often finds expression in acts, for example, public demonstrations and strikes which are to be seen on a daily basis in South Africa. Often an argument is furthered that all anger is bad and should be avoided at all costs. This article develops an alternative (although not unknown at all) line of thought, namely: instead of ignoring and avoiding anger, anger can also be embraced and embodied and that energy that is generated by anger can be used to positive ends. For a full discussion of the connection between anger as an emotion and the embodied expression of that anger, see Cas Wepener, “"Bliksem!” / Damn it!: Ritual-Liturgical Appreciation of a Deadly Sin.”, Verbum et Ecclesia, 36 : 3 (2015), 8 pages. doi: 10.4102/ve.v36i3.1422, as well as Andrew Lester, The Angry Christian. A Theology of Care and Counseling (Louisville, KY: Westminster John Knox Press, 2003), pp. 19-114.

2 Tinyiko Maluleke, 'The Elusive Public of Public Theology. A Response to William Storrar', International Journal of Public Theology, 5 (2011), pp. 88-89. This point regarding anger and the Truth and Reconciliation Commission is confirmed by Sonali Chakravarti in Sing the Rage. Listening to Anger after Mass Violence (Chicago and London: University of Chicago Press, 2014).

${ }^{3}$ See, Antjie Krog, Country of My sSkull (London: Vintage, 1998).
} 
legacy regarding certain policies, such as those related to HIV/Aids, is not unproblematic and was also a stimulus for public expressions of anger.

By taking this very brief look at the past forty years (or thereabouts), starting with the iconic moment in June $1976,{ }^{4}$ it is important to remember that as a nation South Africa has indeed been angry before. The reasons or stimuli for the public anger have been different in every decade. Recently one of the authors of this article published a book on this theme entitled Boiling Point! A Faithful Reaction of a Disillusioned Nation ${ }^{5}$, because according to his observations and analyses, firstly South Africa as a nation is indeed (still) angry and also secondly, there is the conviction that churches and other faith communities can seek meaningful ways to respond to this context of public anger by providing spaces and guidelines for embracing and expressing anger.

The hope expressed in the last chapter of Boiling Point! was that the book would have a short shelf life and that South Africans would hopefully be able to concentrate on other themes in the near future. We (the authors of this article) are convinced that now, three years later, there is even more anger in the South African society. South Africans have been experiencing unprecedented expressions of anger since Boiling Point! was published in 2015, and other authors ${ }^{6}$ have also published on this theme since then. In short, anger has been present in South African society in the past decades; there is currently a new wave of anger sweeping across South Africa, however, as can be seen from the writings of political analysts and

\footnotetext{
${ }^{4}$ Hennie Pieterse, ed, Desmond Tutu's Message. A Qualitative Analysis (Leiden-Boston-Köln: Brill, 2001), pp. 17-25.

${ }^{5}$ Cas Wepener, Boiling Point! A Faithful Reaction of a Disillusioned Nation (Wellington, Bible Media, 2015).

${ }^{6}$ See, for example, Jakub Urbaniak, 'Faith of an Angry People: Mapping a Renewed Prophetic Theology in South Africa', Journal of Theology for Southern Africa 157 (2017), 7-43.
} 
commentators, ${ }^{7}$ but also, and especially, in observing the expressions of anger of the people of South Africa in public spaces.

Political journalist and commentator Justice Malala ${ }^{8}$ writes in We Have Now Begun Our Descent (published at the end of 2015): 'I am angry. I am furious. Because I never thought it would happen to us ... Not us, not the rainbow nation that defied doomsayers and suckled and nurtured a fragile democracy into life for its children.' Later, in his book, he states: 'There is anger in South Africa. Things are not going well ${ }^{9}$ and, again, in the Epilogue Malala writes: 'Every day now we add one more angry young man ... to the deep well of anger and frustration that is growing in South Africa.' Justice Malala is angry; and so is another political analyst and author Eusebius McKaiser, ${ }^{10}$ who found it necessary to devote a whole chapter to anger in his latest book Run Racist Run, ${ }^{11}$ although the whole book's tone is actually drenched in this so-called deadly sin. According to McKaiser, expressing anger is an 'exhibition of moral outrage at that which is broken in society': and, 'anger can sometimes propel us to act' ${ }^{12}$ Twenty-four years after the first democratic elections South Africa can be described as an angry nation. ${ }^{13}$ Embodied expressions of anger can be observed all over the county and are performed

\footnotetext{
${ }^{7}$ Over the past three years there was a lot of anger embedded in several student movements in South Africa. The best known of these protest movements are \#RhodesMustFall (protesting against South Africa's colonial heritage and in favour of active decolonisation), \#FeesMustFall (protesting in favour of free education), \#OutsourcingMustFall, as well as a movement demanding the Decolonisation and Transformation of the Curricula of tertiary education and more.

${ }^{8}$ Justice Malala, We Have Now Begun Our Descent. How to Stop South Africa Losing Its Way. (Johannesburg and Cape Town: Jonathan Ball, 2015), p. 7.

${ }^{9}$ Ibid., p. 68.

${ }^{10}$ Eusebius McKaiser, Run Racist Run. Journeys into the Heart of Racism (Cape Town: BookStorm, 2015).

${ }^{11}$ Ibid.. pp. 149-64.

12 Ibid., pp. 155, 8. See also, Chakravarti, Sing the Rage. pp. 149-153. She writes: 'Anger is not death; it is the opposite of death and has an impact on those who listen to it that is not dependent on being able to respond but rather comes from its expression of the visceral human desire to survive and be heard.' This conviction is shared by practical theologian, Alastair Campbell who writes: 'Like humor, anger can often reflect the human capacity to transcend the immediate situation, gain a new perspective and effect a change for the better - or, if that is not possible, at least register a protest at the wrongness of that which cannot be changed." Alastair Campbell, The Gospel of Anger (London: SPCK, 1986), p. 12.

${ }^{13}$ See also, Cas Wepener, Boiling Point!, pp. 14-25. Before 2015 there were many newspaper articles referring to the incidence and level of public anger in South Africa, but not as many books were published referring directly to the issue until 2015. In a review of 21 at 21. The Coming of Age of a Nation by Sonwabiso Ngcowa and Melanie Verwoerd, Amanda Botha shows how these authors also found anger as one of the patterns that emerged from the
} 
by individuals and groups from all social, economic and racial backgrounds. Protest actions such as \#RhodesMustFall and \#FeesMustFall are driven by anger. ${ }^{14}$ South Africans are angry and the nation has indeed reached boiling poi

It is not only the people mentioned thus far, as well as the authors of this article, who think that our nation is angry: so was the South African President Jacob Gedleyihlekisa Zuma. In a statement to the National Assembly on the $16^{\text {th }}$ of April 2015, Zuma reacted to xenophobic attacks in the country. He rightly said that nothing can justify the attacks and also that South Africans should 'exercise calm and restraint'. ${ }^{15}$ The President subsequently made a connection between the anger of South Africans and psychological illness in a speech delivered at the Union Buildings in the nation's capital city, Pretoria, on the $27^{\text {th }}$ of April 2015 (Freedom Day). ${ }^{16}$ Zuma's call was commendable but, on a technical point, there are many South Africans who differ outright from their former President. It is agreed that aggression ${ }^{17}$ should be avoided; the fact that South Africa is an angry nation is not because the people of the country are psychologically ill. On the contrary. The fact that South Africans are angry - and that they are expressing their anger - is a good sign. They should not be 'cured' of their anger and encouraged to exercise calm: they should instead embody that anger as an act of hope, although guidelines for the expression of such anger is often needed. ${ }^{18}$

\footnotetext{
interviews conducted with 21-year-old South Africans. See, Amanda Botha, 'Vry jeug soek na beloofde land', Rapport Weekliks, 14 (2015).

${ }^{14}$ Malala, We Have Now Begun Our Descent, p. 66.

${ }^{15}$ Gedleyihlekisa Zuma, 'Statement to the National Assembly on the Violence in Kwazulu-Natal Directed at Foreign Nationals', (Cape Town: 16 April 2015), <http://www.thepresidency.gov.za/pebble.asp?relid=19491> [accessed 1 March, 2016].

${ }^{16}$ Gedleyihlekisa Zuma, 'Address During the Freedom Day Celebrations', (Pretoria: Union Buildings, 27 April 2015) https://www.gov.za/speeches/president-jacob-zuma-freedom-day-celebrations-27-apr-2015-0000, [accessed 1 March, 2016)

${ }^{17}$ It is important to distinguish clearly between anger and aggression; this article is about anger, the emotion. See, Lester, The Angry Christian, pp. 67-6.

${ }^{18}$ Ibid. pp. 226-252; Wepener Boiling Point!, pp. 132-156.
} 
The authors of this article as White South Africans, Malala as a Black South African and McKaiser as a Brown South African, all agree with Zuma who spoke out against xenophobia. On his argument that South Africans must be cured of their anger (and that this anger is a sign that there is something wrong with them) there is huge disagreement. ${ }^{19}$ As a nation South Africans should not be cured of their anger, but should rather be assisted to embody and through embodiment express their anger in meaningful ways. Acts of aggressions should be condemned; by way of comparison an expression of anger can also be a sign of hope showing that people still care. ${ }^{20}$

In previous research ${ }^{21}$ one of the authors of this article has argued that expressing anger is not only good, but that anger should be liturgically embraced. In line with this argument the authors want to further an argument in favour of the celebration of angry liturgies. We also wish to advocate for the preaching of angry sermons as an integral part of the on-going road towards reconciliation and healing after apartheid. The pulpit and liturgical spaces in South Africa can learn much from what is already happening in the public spaces in South Africa in this regard. All over South Africa students, workers and citizens have started to embody and enact their anger over questions such as the persisting signs of our colonial past, bad service delivery, cancerous racism and corruption by taking these issues to the streets and other public spaces by means of protest marches and other kinds of demonstrations. The worship spaces of

\footnotetext{
${ }^{19}$ Adriaan Basson, 'Gedleyihlekisa is laughing at you.' News24, (2015), <http://www.news24.com/Columnists/GuestColumn/Gedleyihlekisa-is-laughing-at-you-20150215 > [accessed 1 March, 2016]. The name Gedleyihlekisa means 'The one who laughs at you while physically hurting you.' ${ }^{20}$ Cas Wepener, "'Bliksem!" / Damn it!, pp. 1-8. Many people in South Africa are currently angry because a dream of theirs - the dream of the Rainbow Nation or the New South Africa, is being threatened by corruption and racism. Lester argues that both the anger of God and of humans can be expressions of love. Lester writes: 'God's anger is an expression of love, not a separate character trait', and with regard to humans, he argues: 'that which makes us angry reveals much about our values. In brief: we often become angry because we love. To become angry for the right reasons is not a sin - on the contrary, it is a very necessary expression of love.' Lester, The Angry Christian, pp. 75, 200. Eugene Peterson also argues in favour of using anger as diagnostic tool: 'When we are angry we know we are on to something that matters, that really counts.' Eugene Peterson, A Pastor's Quarrel with God', http://www.christianitytoday.com/le/1993/winter/9311126.html?start=4, [accessed 12 January, 2018).

${ }^{21}$ Wepener, “'Bliksem!"”; Wepener Boiling Point!
} 
the churches in South Africa, which include the pulpits, can learn much from what the citizens of South Africa are already doing in public spaces such as streets, university campuses and city squares. In general, in churches and also in theology in South Africa, anger is firstly and primarily only seen as something bad and a sin. In this regard some theological grounding is necessary.

Anger can turn into negative behaviours such acts of aggression, but anger is not in itself bad. In the first place, anger may be seen from an evolutionary perspective as something that is vital for human survival and as part of God's creation and the way in which God created humans. ${ }^{22}$ Humans become angry when they are being threatened: anger thus becomes an essential emotion that helps people to protect themselves and that which is closest to their hearts. The idea that anger must be summarily classified as a sin, or even worse as one of the seven deadly sins, needs to be challenged. The one reason is that anger is a part of - and a continuing part of - God's creation, and human beings have been created in the image of God. In fact, human beings have been created in the image of a God who also becomes angry. ${ }^{23}$ When looking at anger in the Bible - both the anger of certain characters as well as the anger of God and Jesus - then it is clear, according to Lester, ${ }^{24}$ that anger is generated by love. God becomes angry when God regards it as important to do so, for example, when poor and marginalized people are threatened by injustices. The same applies to people in South Africa they become angry when the things they love and care for are threatened. This emotive response is in no way an idea that is unusual in the Bible or, with regards to God. In many biblical texts

\footnotetext{
${ }^{22}$ Lester The Angry Christian, 54-66, 115-188. In general Lester develops a substantial argument regarding, firstly, the place of emotion in theology and, secondly, the place of anger.

${ }^{23}$ Campbell refers to the huge complexity in the biblical texts with regard to God's wrath and concludes: 'Perhaps the dark shadow of destructive aggression emanating from divine wrath is just our limited view of the brilliance of divine love.' Campbell, The Gospel of Anger p. 43

${ }^{24}$ Lester The Angry Christian pp. 205-206. See also Cas Wepener, "Woedende dominee: 'Ek is die bliksem in omdat ek liefhet!"” Beeld https://www.netwerk24.com/Stemme/Aktueel/Woedende-dominee-Ek-is-die-bliksemin-omdat-ek-liefhet-20150429 (accessed 13/01/2018).
} 
God was filled with wrath and a number of psalms make it evident that this affective response is not a case of attempting to fit God into our contemporary discourses on intimacy and love of peace. There are many descriptions of a wrathful God in the Bible. ${ }^{25}$

As part of an on-going research project we now reflect on sermons preached on the theme of anger in Afrikaans Reformed churches in South Africa between 2010 and 2015. The collected sermons were analyzed by means of content analysis. The result of this analysis is insightful with reference to the existing positive qualities as well as potential shortcomings. We examine how some ministers are currently preaching on the theme of anger and on that basis develop a homiletical theory for praxis and provide, in conclusion, what can be called homiletical route markers for angry preaching in South Africa in the year 2018.

\section{Content analysis of sermons making use of a grounded theory methodology.}

This article considers sermons that were preached between 2010 and $2015 .{ }^{26} \mathrm{We}$ decided to focus on Afrikaans sermons: there are very many variables that play a role with regards. Our focus is on sermons preached in Afrikaans in Reformed churches which are still predominantly white. These churches in the Reformed tradition include the Reformed Churches in South Africa, the Netherdutch Reformed Church of Africa as well as the Dutch Reformed Church. We collected as many sermons as we could get from the internet. We located just over twenty

\footnotetext{
${ }^{25}$ A similar argument can be developed with regards to Jesus based on the descriptions in the Gospels of his expression of anger: examples included Jesus making a whip and droiving everyone, even the sheep and cattle, out of the Temple, overturning the tables of the money-lenders and throwing their money to the ground..

${ }^{26}$ Within the context outlined in the introduction, as well as the engagement with the sermons studied that were preached in that specific context, this article can be seen as an example of what Etienne de Villiers calls 'engaged public theology'. It develops a praxis theory by means of engagement with the ritual-liturgical and homiletical praxis of people at a grass roots level in South Africa. See Etienne de Villiers, 'Editorial. Special Issue Responsible South African Public Theology in a Global Era', International Journal of Public Theology, 5 (2011) 2. The authors of this article also view liturgy and worship as public liturgy and worship as understood in the Reformed tradition. As Lukas Vischer observes: 'Reformed worship has always been public worship. The proclamation of the word has never been confined to spiritual themes but has also included aspects of public life.' Lukas Vischer, 'Worship as Christian Witness to Society', in Lukas Vischer, ed, Christian Worship in Reformed Churches Past and Present (Grand Rapids, MI, 2003) pp. 415-426 at p. 415.
} 
sermons either as full texts or as podcasts. The podcasts were transcribed and we could thus focus on the printed texts of all the sermons.

We decided to use the grounded theory qualitative method of content analysis to analyse what the preachers were saying in their sermons. Every grounded theory analysis project is slightly different from the others. We drew upon the methodology of Kathy Charmaz ${ }^{27}$ following Barney Glaser's ${ }^{28}$ line on grounded theory. During this period three grounded theory homiletical studies of sermons were published. ${ }^{29}$ From the perspective of a public theology this approach is an example of an interdisciplinary study. It is a tested, academic methodology in homiletics, also in the social sciences.

\section{Open coding of four sermons}

By means of theoretical sampling we selected four sermons on anger/fury from the sermons published on the internet. We analysed these four sermons as a first step by means of open coding. Directed by the research question - namely, how preachers in Afrikaans Reformed Churches in South Africa preached on anger during the period 2010-2015 - and our homiletical concern, we divided the sermons into meaningful parts following in a natural way in the course of the sermon. We attached an open code to each segment of content in a single statement. The result of the open coding is set out below.

Preacher A. (Nederduitse Gereformeerd Kerk; text: Ephesians 4:26-32).

\footnotetext{
${ }^{27}$ Kathy Charmaz, Constructing Grounded Theory. A Practical Guide through Qualitative Analysis (London: Sage, 2006).

${ }^{28}$ Barney Glaser, Theoretical Sensitivity. Advances in the Methodology of Grounded Theory. (Mill Valley, CA: Sociology Press, 1978).

${ }^{29}$ Theo Pleizier, Religious Involvement in Hearing Sermons. A Grounded Theory Study in Empirical Theology and Homiletics (Delft: Eburon Academic Publishers, 2010); Hennie Pieterse, 'An Emerging Grounded Theory for Preaching on Poverty in South Africa with Matthew 25: 31-46 as Sermon Text ', Acta Theologica, $33: 1$ (2013), 175-96; Hennie Pieterse, 'Theoretical Strengthening of the Concept of Appealing in Analyzed Sermons on Matthew 25: 31-46 in the Context of Poverty in South Africa', In die Skriflig/In Luce Verbi 47:1 (2013), Art. \#692,8 pages. http://.doi.oerg/10.4102/ids.v47i1.692; André Verweij, Positioning Jesus' Suffering. A Grounded Theory of Lenten Preaching in Local Parishes (Delft: Eburon Academic Publishers, 2014).
} 
Code 1. Anger/fury is bad for the health of your heart.

Code 2. In South Africa everyone is angry with everyone. In Sub-Sahara Africa 52\% of people don't trust their own family.

Code 3. God wants us to love each other.

Code 4. Basic trust of others means a life open to others, like that of Jesus.

Code 5. Respect other people (Matthew 25:31).

Code 6. Do good to others every day. See people through the eyes of Christ.

Code 7. Live happily in a festive mood (Luke 16).

Preacher B. (Nederduitse Gereformeerde Kerk; text: Ephesians 4:25-32).

Code 1 . Justified anger/fury is part of your daily life.

Code 2. One must communicate your anger in a Christian manner.

Code 3. You have to submit your unjustified anger, resentment, to God to take it away from you.

Code 4. One must not become embittered.

Code 5. Don't hurt others with words - respect them.

Code 6. Practice kindness, care and forgiveness of other people.

Preacher C. (Nederduitsch Hervormde Kerk van Afrika; text: Matthew 5:20).

Code 1. Anger/fury is meant to hurt people.

Code 2. To overcome anger you have to surrender your will to God.

Code 3. Communicate with others who anger you in a Christian way.

Code 4. One must love other people to overcome hatred of them.

Code 5. Make peace with those with whom you are in conflict.

Preacher D. (Gereformeerde Kerke in Suid-Afrika; text Psalm 73:26-28).

Code 1 . People are angry about murders of farmers. 
Code 2 . Anger/fury is a reality of our daily experiences.

Code 3. Anger/fury and bitterness are bad for your health - physically and spiritually.

Code 4. Anger/fury hurts other people and yourself.

Code 5. Take your anger and bitterness to God in the worship service/liturgy.

Code 6. Find your peace of mind in Jesus Christ.

The core code (from the open coding process) to which the other codes relate is: bring your anger and bitterness to God worship in order to be liberated from them and then act in a Christian way. The codes which have same content in the four sermons can be integrated into initial categories that relate to the core code as a result of constant comparison: that is a necessary step in grounded theory analysis. ${ }^{30}$ A category is a unique piece of content that does not overlap with another category in a conceptual framework.

\subsection{Initial categories as a result of open coding}

A clear pattern emerged from the open coding. First, preachers say that anger/fury is an experience of all people in our country. Second, the result of this anger is that it hurts people and is bad for our health - physically and spiritually. Third, the question arises of how we should we handle our anger. The preachers say: take it to God in the worship service. This is clearly the core code to which all the other codes relate. Fourth, then the preachers advise on the basis of the gospel how to regard and to communicate with others in conflict situations.

Category 1. All people are angry (Supported by codes A2, B1, D1 and 2, E1, F1, G1, H1, I 1).

(Open coding Category 2. Anger is bad for health and spirituality. After selective coding Category 2 is strengthened as follows):

\footnotetext{
${ }^{30}$ Verweij, Positioning Jesus' Suffering, pp. 68, 71-73.
} 
Category 2. Anger is bad for health, spirituality and destroys relationships. (Supported by codes A 1 and 2, B5, C1, D3 and 4, H1).

(Open coding Core Category. Bring your anger to God in worship. After selective coding Core Category is strengthened as follows):

Core category. Bring your anger to God in liturgy (prayers). (Supported by codes B3, C2, D5 and 6, F1, G2, H2, I 1).

(Open coding Category 3. Love other people as God does. After selective coding Category 3 is strengthened as follows):

Category 3. Love other people as God does in new thinking and good actions. (Supported by codes A3, 6 and 7, B6, C2 and 4, E1, G1).

Category 4. Trust other people. (Supported by code A 4).

Category 5. Respect other people. (Supported by codes A 5, B 5).

Category 6. Communicate anger in a Christian way. (Supported by codes B2, C3).

Category 7. Make peace with those you are in conflict. (Supported by codes C5, D6).

\section{Selective coding of five sermons}

In grounded theory we need a second phase in the process of content analysis - selective coding. ${ }^{31}$ Selective coding is a process in which new sermons are collected in order to enrich the emerging initial categories with more characteristics. More categories may emerge too. Selective coding means using the most significant and frequent earlier codes (now initial

${ }^{31}$ Charmaz, Constructing Grounded Theory, p. 57; Theo Pleizier, Religious Involvement in Hearing Sermons, p. 88. 
categories) to sift through new data and thicken the categories. We selected another five sermons from the published sermons on the internet for that reason.

Preacher E. (Nederduitse Gereformeerde Kerk; text Romans 12).

Code 1. All people are angry.

Code 2. Overcome anger with good actions.

Preacher F. (Nederduitsch Hervormde Kerk van Afrika; text Genesis 4:1-16)

Code 1. All of us are furious.

Code 2. Go to God with your anger and bitterness.

Preacher G. (Nederduitse Gereformeerde Kerk; text Mathew 5:20-26).

Code 1. All of us experience anger.

Code2. Jesus brings new thinking.

Code 3. Resolve your anger in the liturgy (prayer).

Preacher H. (Nederduitse Gereformeerde Kerk; text Matthew 5: 21-26)

Code 1. Anger is normal in South Africa.

Code 2. Anger/fury destroys relationships.

Code 3. Take your anger into liturgy (prayer).

Preacher I. (Nederduitse Gereformeerde Kerk; no text provided).

Code 1 . All of us get angry.

Code 2. Take anger into liturgy - specifically prayer. 


\subsection{Result of the selective coding}

All five sermons have as a first statement that all South Africans are angry. We are not repeating those codes here, but this strengthens the initial category 1: (E1, F1, G1, H1, I1).Some initial categories are also strengthened, namely categories 2, 3 and the core category. We have written it in this new formulation in the initial categories. In the core category the word 'liturgy' is brought in. In the liturgy the emphasis is on prayer only. The initial categories now become categories that we work with as the contents of the sermons which we have analysed. There is no mention in any of the sermons of rituals in liturgy other than prayer that can be meaningful with regard to dealing with our anger/fury. In our view the absence of anything more than prayer is a shortcoming/deficiency in the sermons.

\section{Theoretical coding}

In theoretical coding we look for a theory from the practice of preaching that emerges as a theory of how to preach in the current context of anger amongst our people. ${ }^{32}$ The categories are now put in relation to the core category to demonstrate the emerging theory. The categories can now be formulated as concepts. The emerging theory that we derived from the sermons can be summarised in three 'R's', namely the reality, the remedy and the result.

A. The reality: Anger exists and anger is bad for a person's health.

B. The remedy: Take the anger, place it within the liturgy and specifically in prayer.

C. The result: A person who has done the above may experience love, trust, respect, better communication as well as peace making.

In this emerging theory concept B is the core concept and is, therefore, placed in the middle. The other two stand in relationship to concept B as well as to each other.

${ }^{32}$ Pleizier, Religious Involvement in Hearing Sermons, p. 88. 
The theory that emerges is helpful inasmuch as it articulates what is happening when the theme of anger is being preached upon in some (predominantly white) Afrikaans Reformed churches. Preachers do well to articulate that this emotion actually exists; they also recommend taking such anger to God in prayer as well as calling for good communication and respect. In spite of these commendable strengths, we are convinced that this emerging theory can be further enriched by means of a deeper appreciation and understanding of exactly what anger is and is not - how it might be expressed in and address to our current challenging public context in South Africa.

It should first be emphasised that anger should not be confused with aggression, which is an act of violence. ${ }^{33}$ Anger as an emotion is necessary for our survival as a bodily indicator that something is wrong. As Eugene Peterson puts it: 'When anger erupts in us, it is a signal that something isn't working right. There is evil, or incompetence, or stupidity lurking about., ${ }^{34}$ In the light of the basic insight that anger as an emotion is part of God's creation and is important for our survival, and that it can also serve as a diagnostic tool, ${ }^{35}$ we believe that it might be helpful to augment the emerging theory. As also argued in previous research, ${ }^{36}$ we believe it is important to work with a bodily based epistemology which assumes that the act of preaching can be more than mere instruction: it can also be a liturgical ritual which is performed to serve a noetic function. ${ }^{37}$ With this in mind we conclude with some homiletical route markers for angry preaching.

\footnotetext{
${ }^{33}$ Lester, The Angry Christian, pp. 67-74.

${ }^{34}$ Peterson, 'A Pastor's Quarrel with God'.

${ }^{35}$ Wepener, BoilingPoint!, pp. 134-135.

${ }^{36}$ Wepener, 'Bliksem! / Damn it'; Cas Wepener, 'The Department of Faith Practices at the University of Pretoria. A spacious House Accommodating a Postcolonial African Pneumapraxis where an Academic Spirituality of Liminality is fostered', Inaugural Lecture, (Pretoria: University of Pretoria, 5 November 2015).

${ }^{37}$ Theodore Jennings, 'On ritual knowledge', in R.L. Grimes, ed., Readings in ritual studies (Upper Saddle River, NJ: Prentice Hall, 1996), pp. 324-34.
} 


\section{Homiletical route markers for angry preaching}

In order to enrich the emerging theory, we will present our conclusion as homiletical route markers for preaching anger. Our route markers augmenting the emerging theory are partially inspired by our theory of anger as an emotion, and that holy anger at, for example, injustice is an expression of love. This theory correlates closely with the work of J.K.A. Smith ${ }^{38}$ entitled Desiring the Kingdom: here he describes the human person as homo liturgicus. In other words this homo liturgicus is a lover or desirer in which that person's primordial orientation towards the world is one of love: "we feel our way around the world" ${ }^{39}$ in and through our bodies, of which emotions are an integral part. 'We are what we love, and our love is shaped, primed, and aimed by liturgical practices that take hold of our gut and aim our heart to certain ends. ${ }^{40}$

We regard preaching as a liturgical ritual, ${ }^{41}$ or a liturgical act which should communicate content not only in an abstract and exclusively rational way. Preaching is an embodied liturgical ritual that should conquer the hearts (kardias) of the hearers and draw them into a vision and experience of God's possibilities, possibilities that cannot be neatly summarised in Power Point slides as ideas or abstract values. ${ }^{42}$ This reality has implications for faith formation. Smith argues that it is not primarily what we think that shapes us, but what we love. This love can, of course, be misdirected, and so can anger be misdirected. It is exactly at this point that we want to introduce our route markers, namely to direct our preaching on anger and develop it into

\footnotetext{
${ }^{38}$ James Smith, Desiring the Kingdom. Worship, Worldview, and Cultural Formation, Cultural Liturgies vol. 1 (Grand Rapids, MI: Baker Academic, 2009), as well as James Smith, You Are What You Love. The Spiritual Power of Habit (Grand Rapids, MI: Brazos Press, 2016).

${ }^{39}$ Smith, Desiring the Kingdom, 47.

${ }^{40}$ Ibid., p. 40.

${ }^{41}$ cf. Marcel Barnard, Johan Cilliers and Cas Wepener, Worship in the Network Culture. Liturgical Ritual Studies. Fields and Methods, Concepts and Metaphors, Liturgia Condenda 28, (Leuven, Paris, Walpole, MA: Peeters, 2014); Albrecht Grözinger, Homiletik (Gütersloh: Gütersloher Verlagshaus, 2008), p. 287.

${ }^{42}$ Smith, Desiring the Kingdom, p. 42.
} 
fully fledged angry preaching which is an expression of love, of the fact that we care, of our desire for the Kingdom of God.

We find a commonality of purpose and vision here with the Afrikaans poet Sheila Cussons. Wiritng in her poem entitled 'Advent', Cusson envisages how 'God's anger erupted from His heart in a rose of flesh.' Anger can be extremely dangerous; the angry preaching and angry liturgies for which route markers are developed here should be liturgical rituals, however, erupting from liturgists' and preachers' hearts to touch the hearts of hearers, because of the rose of flesh.

Our route markers are as follows:

- From preaching anger to angry preaching: a neutral tone when preaching on the theme of anger is not desirable. Preachers should not preach dispassionately about anger, and preaching anger must become angry preaching in the pulpit. Here much can be learned from McKaiser, who says that he refuses to treat the injustices in South Africa as primarily intellectual challenges. 'They are not. They are not. They are real, material challenges and it is unhelpful, and frankly inhumane, to only examine inequality, poverty, racism, misogyny, violence and other ills dispassionately.' ${ }^{43}$ McKaiser's passion is such that he can say in the most forthright way possible: 'I am angry. I am fucking angry. I am angry at the profound levels of injustice in our country that refuse to go away. ${ }^{44}$ The preacher should embody the content of the sermon in its performance, which will ask much from the listeners, which is our second route marker. $^{45}$

\footnotetext{
${ }^{43}$ McKaiser, Run Racist Run, p. 10.

${ }^{44}$ Ibid., pp. 9-10.

${ }^{45}$ Rudolf Bohren, Predigtlehre (München: Chr. Kaiser Verlag, 1974), p. 381. Gerrit Immink, 'Een methode van preekvoorbereiding', in Henk van der Meulen ed., Als een leerling leren preken (Zoetermeer: Boekencentrum, 2010), pp. 9-20 at 14.
} 
- Angry preaching needs angry listening: Reformed Christians should give such a preacher the chance to deliver her or his passionate sermon and not dismiss such an act as an intellectual failure on the basis of the emotion that is involved. This type of sermon and its way of preaching should not be seen as a sign of weakness and thus an embarrassment that will hopefully be over fairly soon. In much the same way as the preachers should embody this anger, so those who hear should open themselves to be receivers of such angry sermons, even if the anger is not directed at them specifically. ${ }^{46}$ There is, of course, a place for calm and collected thoughts and sermons, but that is what is almost always the preferred mode in Reformed congregations in South Africa. Some exceptions are needed today.

- The last route marker is that within the worship service as a Gesamtkunstwerk $^{47}$ angry preaching should not stand alone. It should be supported by all the other elements or liturgical rituals of that particular worship service, so that angry preaching fits within an angry liturgy. There are prayers, lament Psalms, hymns and other elements that can be utilised to support such preaching. ${ }^{48}$ To cite one student from Cape Town during a \#FeesMustFall workshop early in 2016: 'I needed a place to be Christian and angry. ${ }^{\text {,4 }}$

We believe God's anger being an expression of God's love; for the sake of a common good and a faith that bears witness to public failure we believe in angry preaching and angry liturgies in South Africa at this particular point in time.

\footnotetext{
${ }^{46}$ Grözinger, Homiletik, pp. 99-22; Gijsbert Dingemans, Als hoorder onder de hoorders (Kampen: Kok, 1991).

${ }^{47}$ Elsabe Kloppers, 'Die erediens as omvattende kunswerk', Nederduitse Gereformeerde Teologiese Tydskrif, 44:1/2 (2003), 80-8, as well as Cas Wepener \& Mirella Klomp, 'D(i)e verhouding prediking, mus(z)iek en liturgie', HTS Teologiese Studies/Theological Studies 71(3) (2015) Art. \#2992, 8 pages. http://dx.doi.org/10.4102/hts.v71i3.2992

${ }^{48}$ Cas Vos, Theopoetry of the Psalms (Pretoria: Protea Boekhuis, 2005); Wepener Boiling Point!

${ }^{49}$ Caroline Powell, 'The Church, Inequality and Civil Unrest. How to Host Tough Conversations in Safe Spaces', The Good Hope (2016). http://www.ctdiocese.org.za/Data/Sites/1/pdf/doc-good-hope-may-2016-.pdf (accessed 06/09/2018).
} 